
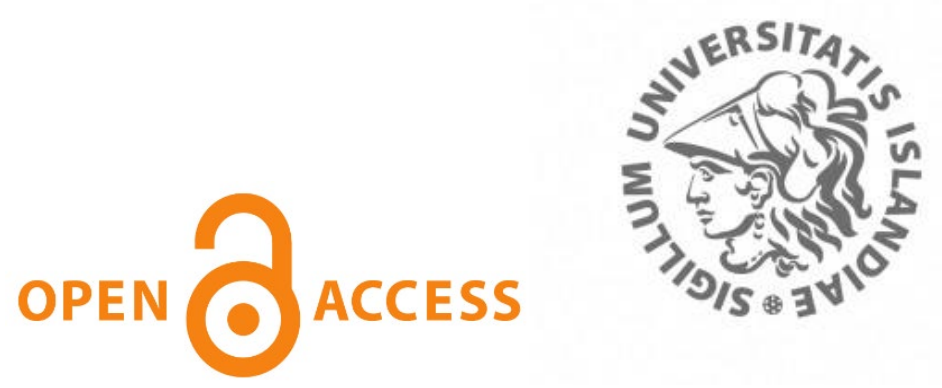

O. Opin vísindi

This is not the published version of the article / Petta er ekki útgefna útgáfa greinarinnar

Author(s)/Höf.: $\quad$ Cook, D., Malinauskaite, L., Roman, J., Davíđsdóttir, B., \& Ögmundardóttir, $\mathrm{H}$.

Title/Titill: Whale sanctuaries - An analysis of their contribution to marine ecosystem-based management

Year/Útgáfuár: $\quad 2019$

Version/Útgáfa: $\quad$ Post-print (lokagerð höfundar)

Please cite the original version:

Vinsamlega vísið til útgefnu greinarinnar:

Cook, D., Malinauskaite, L., Roman, J., Davíđsdóttir, B., \& Ögmundardóttir, H. (2019). Whale sanctuaries - An analysis of their contribution to marine ecosystem-based management. Ocean \& Coastal Management, 182, 104987. doi:https://doi.org/10.1016/j.ocecoaman.2019.104987

Rights/Réttur: $\quad$ C 2019 Elsevier Ltd. All rights reserved. 


\section{Whale sanctuaries - an analysis of their contribution to marine ecosystem- based management}

David Cook (corresponding author), Environment and Natural Resources, School of Engineering and Natural Sciences, University of Iceland, Gimli, Sæmundargötu 2, 101 Reykjavík, Iceland, email: dac3@ @i.is, tel: +354 6618998.

Laura Malinauskaite, Environment and Natural Resources, Faculty of Social and Human Sciences, University of Iceland, Gimli, Sæmundargötu 2, 101 Reykjavík, Iceland, email: lam6@hi.is

Joe Roman, Gund Institute for Environment, Rubenstein School of Environment and Natural Resources, University of Vermont, Johnson House, 617 Main Street, Burlington, VT, United States, email: joseph.roman@uvm.edu

Brynhildur Davíðsdóttir, Environment and Natural Resources, Faculty of Economics and Faculty of Environment and Life Sciences, University of Iceland, Oddi, Sæmundargötu 2, 101 Reykjavík, Iceland, email: bdavids@ hi.is.

Helga Ögmundardóttir, Faculty of Social and Human Sciences, University of Iceland, Gimli, Sæmundargötu 2, 101 Reykjavík, Iceland, email: helgaog@hi.is 
Keywords: whales; sanctuary; ecosystem services; marine protected areas; ecosystem-based management

Goal 14, 'Life Below Water', of the United Nations Sustainable Development Goals sets a target for nations to increase the number of marine protected areas managed using ecosystembased management, which requires interventions focused on fish stock conservation and enhancement, environmental sustainability and ecosystem services of benefit to human beings. Although not adhering to the International Union for Conservation of Nature's criteria for marine protected areas, whale sanctuaries are an increasingly common approach to conservation around the world. This paper is the first in the academic literature to use a case study approach to review the extent to which whale sanctuaries contribute to ecosystem-based management. A fifteen-criteria framework for marine ecosystem-based management is applied with reference to six whale sanctuary case studies, including the International Whaling Commission's two designations in the Indian Ocean and Southern Ocean. The review underscores the generally very limited contribution of whale sanctuaries to ecosystembased management, unless they are explicit in stating conservation goals and embedding these within iterative management plans. The Hawaiian Islands Humpback Whale National Marine Sanctuary is cited as an example of an approach that comes closest to fulfilling the objectives of ecosystem-based management, albeit its designation lacks consideration of ecosystem dynamics and the interrelationships between multiple economic actors operating within its boundaries. In order to meet the requirements of Goal 14, the case studies in this paper reveal advancements necessary for whale sanctuaries to transition towards ecosystem-based management: establishment of objectives broader than the conservation of whale stocks, assessment of the contribution of the sanctuary to human well-being and trade-offs in ecosystem services, accounting for ecological and socio-economic dynamics, and ensuring broad stakeholder consultation and participatory adaptive management.<smiles>[13CH3][13CH3]</smiles> 


\section{Introduction}

In recent years, marine protected areas (MPAs) have been increasingly applied round the world as a governance strategy for the conservation of marine resources (Gruby et al., 2015; Christie et al., 2017; Giakoumi et al., 2018). The global policy agenda has continued to reinforce the importance of MPAs, from the Resolution of the $17^{\text {th }}$ Assembly of the International Union for Conservation of Nature (IUCN) in 1987 up to the Aichi Targets set during the tenth Conference of Parties meeting of the United Nations Convention on Biological Diversity, which set an aspirational target for $10-30 \%$ of the world's oceans to be designated as MPAs (Christie et al., 2017). Most recently, Goal 14 of the United Nation's Sustainable Development Goals (SDGs), 'Life below water', pursues the conservation and sustainable use of marine resources, reinforcing the Convention on Biological Diversity by setting a target (14.5) for at least $10 \%$ of coastal and marine areas to be conserved in line with national and international law by 2020 (United Nations, 2015). This is a goal which would appear to have already been met on a global scale - in July 2017, an estimated $14.4 \%$ of coastal and marine areas under national designations were classified as protected areas (UNEP-WCMC, 2017). Debate is now shifting from concerns about the level of designation to the degree of effectiveness of MPAs (Watson et al., 2014; Jones and de Santo, 2016).

In order for MPAs to be effective, they need strong governance in order to influence human behaviour and reduce negative ecosystem impacts (UNEP-WCMC, 2017), but must also deliver social, economic and environmental benefits for user communities (Jones and de Santo, 2016; UNEP-WCMC, 2017). Target 14.2 of the United Nation's SDGs stresses the importance of sustainable management and protection of marine and coastal ecosystems to avoid significant adverse impacts, strengthening resilience, and taking action to ensure restoration in order to achieve healthy and productive oceans (United Nations, 2015). Healthy, resilient and productive oceans demand environmentally sustainable marine ecosystems and, as such, the indicator linked to Target 14.2 is the proportion of national exclusive economic zones managed using ecosystem-based approaches.

Ecosystem-based approaches to marine management are generally considered to be broadranging and holistic, with a focus not only on the sustainability of bio-resources but also socio-ecological objectives. Definitions abound, however, the United Nations Convention on Biological Diversity's version has been widely cited due to its integration of ecological, social and governance objectives: "a strategy for the integrated management of land, water and living resources that promotes conservation and sustainable use in an equitable way" (United Nations Convention on Biological Diversity, 2011, p.6). Other definitions go further and stress the importance of marine resources in terms of their contribution to humans. The Communications Partnership for Science and the Sea (COMPASS) provides one such example, defining ecosystem-based management as: "an integrated approach to management that considers the entire ecosystem, including humans. The goal of EBM [ecosystem-based management] is to maintain an ecosystem in a healthy, productive and resilient condition so that it can provide the services humans want and need." (COMPASS, 2005, p.1). The COMPASS depiction of EBM chimes with the recent calls of Jones and de Santo (2016) and UNEP-WCMC (2017) for the social, economic and environmental benefits - or, ecosystem services - of MPAs to be considered when evaluating their success.

In contrast to EBM, MPAs have traditionally been adopted in order to restrict or ban one or more economic activities which is considered unsustainable or undesirable (Murawski et al., 2005; Potts et al., 2014; Hilborn, 2016). Restrictions in MPAs have commonly related to the 
temporary or permanent closure of areas for harvesting - most commonly fisheries (Unsworth et al., 2010), although in recent years also whale harvesting (Hoyt, 2012) and mineral and hydrocarbon extraction (Kark et al., 2015). Whale sanctuaries exhibit the common theme of MPAs in the sense that they ban an industrial activity, commercial whaling (Gerber et al., 2005; Hoyt, 2012), but there are currently no academic studies reviewing the extent to which they contribute to EBM. This is surprising considering the International Whaling Commission's two whale sanctuaries in the Indian and Southern Oceans were, for many years, the world's two largest MPAs. Although this paper has insufficient space to provide a comprehensive review of all MPAs and the extent to which they adhere to principles of marine EBM, this paper has chosen a case study approach, aiming to (a) provide a starting point in observing the extent to which whale sanctuaries currently do so, and (b) reflect on how whale sanctuaries could transition from their current status as protected areas to a contributing force for EBM, as demanded by Target 14.2 of the UN's SDGs.

This paper is structured as follows. Section 2 provides a conceptual background, defining whale sanctuaries and analysing the reasons why they commonly sit outside of the IUCN's various categories of MPAs, before exploring the links between ecosystem services, environmental sustainability and EBM in a marine context, and finally setting out a framework for evaluating marine EBM utilising the key principles delineated by Long et al., (2015). Section 3 provides a brief outline of each case study and this paper's evaluative methods. Section 4 communicates the results, evaluating each of the selected whale sanctuaries against Long et al's framework, and details a synthesis of the overall findings, citing examples from the respective case studies. Section 5 discusses the key issues in relation to the how whale sanctuaries might transition to marine EBM, before section 6 provides a short conclusion and recommendations for future research.

\section{Conceptual background}

\subsection{Whaling and establishment of whale sanctuaries}

International law concerning whaling was first established through the International Convention for the Regulation of Whaling (ICRW) in 1946. The ICRW states that the objective of the convention is "to achieve the optimum level of whale stocks as rapidly as possible without causing widespread economic and nutritional distress" (ICRW, 1946, p.3). Article III of the ICRW established the International Whaling Commission (IWC) and Article IV outlined the scope of the organisation's duties, which included monitoring of whale stocks, compiling scientific and statistical reports, protecting certain species, and reviewing different methods for maintaining and increasing populations of whales. Article V granted the IWC the right to apply regulations to ensure the conservation and utilisation of whale stocks, including, in part (c), the designation of "open and closed waters, including the designation of sanctuary areas" (ICRW, 1946, p.5).

Although defined in no further detail, it is clear from the overall context of Article $\mathrm{V}$ of the ICRW that the term "sanctuary areas" was understood in specific and narrow terms to be a marine area where no whaling took place in order to promote the conservation of whale stocks. The IWC has been responsible for the creation of two whale sanctuaries - the first, covering the whole of the Indian Ocean south to $55^{\circ} \mathrm{S}$, was established in 1979 , and the 
second, in the Southern Ocean around Antarctica, was formed in 1994 (IWC, n.d.). In addition to the IWC's two designations spanning international waters, there exist an increasing number of national whale sanctuaries around the world. These also apply zero catch limits but are designated in national waters, often up to the 200 nautical mile limit of the exclusive economic zone (Hoyt, 2012).

Following criticisms that the IWC's whale sanctuaries were applied as a political rather than a scientific tool (Gerber et al., 2005), three scientific objectives of whale sanctuaries were specified in relation to the Southern Ocean Sanctuary (IWC, 1998, p.3):

- The recovery of whale stocks, including the undertaking of appropriate research upon and monitoring of depleted populations;

- The continuation of the Comprehensive Assessment of the effects of setting zero catch limits on whale stocks;

- The undertaking of research on the effects of environmental change on whale stocks.

\subsection{Whale sanctuaries in relation to the IUCN's protected areas classification}

The IUCN defines protected areas as follows: "A clearly defined geographical space, recognised, dedicated and managed, through legal or other effective means, to achieve the long-term conservation of nature with associated ecosystem services and cultural values." (IUCN, 2008, p.2). This definition is closely aligned to COMPASS's interpretation of marine EBM, which emphasises the importance of focus on ecosystem service implications. Through adherence to the IUCN's overarching definition, a spatial area may then qualify for one of six protected area categories: Ia (strict nature reserve); Ib (wilderness area), II (national park), III (natural monument or feature), IV (habitat/species management area), V (protected landscape or seascape), and VI (protected areas with sustainable use of natural resources) (IUCN, 2008). Caveats apply in a marine context, however, and often prevent spatial areas from receiving formal MPA status in line with the IUCN's classification. These are often areas that might deliver at least some nature conservation and ecosystem service benefits, but have no stated conservation objectives (Day et al., 2012). Examples include fishery management areas with no broader assertions of conservation aims, community areas managed mainly for sustainable extraction of marine products (e.g. fish, coral, whale meat etc.), marine and costal management systems primarily focused on tourism but happening to also include areas of conservation interest, and large areas where species are protected by law (Day et al., 2012).

The IWC's whale sanctuaries, which are oceanic in scope, are unlikely to deliver comprehensive protection for whales, or indeed other marine species, since the designated area is large, extending beyond national waters and into the lightly monitored high seas (Hoyt, 2005). Equally, national-scale or smaller whale sanctuaries, although widely perceived and purported as protected areas, do not commonly fall within the IUCN's classification due to the absence of stated conservation objectives and specific management activities tasked with conservation (Agardy et al., 2011). Some whale sanctuaries can, in theory, fall within IUCN protected area category IV, provided they are explicit in stating their conservation objectives within legal documentation and conduct monitoring and long-term management activities (Hinch and de Santo, 2011). There currently exists just one example, the Hawaiian Islands Humpback Whale Sanctuary in the United States, which has been designated as a category IV site (UNEP-WCMC and IUCN, 2018). 
EBM requires not only interventions to ensure the ecological integrity of a resource, but the broader consideration of impacts to human well-being in the form of ecosystem services. This understanding is akin to Goodland's widely cited conceptualisation of environmental sustainability, which was grounded in ideals of conservation and the promotion of human well-being. Goodland (1995, p.4) opined that the objective of environmental sustainability is to "improve human welfare by protecting the sources of raw materials used for human needs and ensuring that the sinks for human wastes are not exceeded in order to prevent harm to humans". Implicit in this depiction is the understanding of a positive contribution to human well-being from provisioned raw materials and potential for negative effects in other ways through environmental consequences, should the waste materials of human activity be excessive (Olafsson et al., 2014; Cook et al., 2017).

This conceptualisation can be reinforced through more direct linkages to the ecosystem services concept. The third of the OECD's five criteria for environmental sustainability was improving quality of life for human beings (OECD, 2001). Moldan et al. (2012) contend that fulfilling this goal requires the maintenance of ecosystem services at a given level of quality and quantity across multiple spatial and temporal scales, and also confers upon governance institutions a duty of care to intervene and manage ecological infrastructure in keeping with his objective. These interactions and interventions are the core principles of EBM, albeit, in a marine context, management choices have not tended to focus on interactions between ecological and human systems, but more narrowly on biodiversity conservation (Cook et al., 2019).

\subsection{A framework for evaluating marine EBM}

In recent years, a lack of consensus emerged concerning the constituent elements of EBM in a marine context. This is despite widespread agreement about the importance of acknowledging the complexity of socio-ecological systems, need for stakeholder participation, and necessity for incentives to encourage biodiversity conservation (Arkema et al., 2006; Crowder and Norse, 2008; Charles, 2012). Due to the plethora of definitions, a universal framework for EBM in a marine context was lacking.

The recent literature review and synthesis conducted by Long et al. (2015) advanced progress concerning the core principles of EBM in a marine setting. The authors applied a frequency analysis of the extensive marine EBM literature, from which fifteen major principles emerged. Although there is some overlap between the respective components, their study provided a very useful means of synthesising the existing literature and a practical way of beginning to consider the extent to which a marine governance system accords with EBM, in so doing identifying its main deficiencies.

The fifteen core principles of marine EBM, as determined by Long et al.'s review, are reproduced in Fig. 1. Each component is then clarified further in Table 1 with respect to its evaluative criteria in the ensuing case study analysis. 
Fig. 1: Main EBM principles listed in increasing frequency of importance (Sourced from Long et al. 2015)

Table 1: Definitions of key marine EBM principles (Source: Long et al., 2015)

\begin{tabular}{ll}
\hline Principle & Criteria \\
\hline $\begin{array}{l}\text { Acknowledge } \\
\text { uncertainty }\end{array}$ & $\begin{array}{l}\text { Applies a precautionary approach to management and } \\
\text { conservation in plan and policy making }\end{array}$ \\
\hline Appropriate monitoring & $\begin{array}{l}\text { Tracks changes in whale stocks for management purposes } \\
\text { and ensures no whaling activity in sanctuary }\end{array}$ \\
\hline Interdisciplinarity & $\begin{array}{l}\text { Bases management decisions on scientific understanding } \\
\text { from several disciplines, including ecology, economics and } \\
\text { sociology }\end{array}$ \\
\hline Distinct boundaries & Defines the spatial boundaries of the whale sanctuary \\
\hline Decisions reflect & $\begin{array}{l}\text { Management plans and polices for the whale sanctuary } \\
\text { reflect the consensus obtained via stakeholder consultations }\end{array}$ \\
\hline $\begin{array}{l}\text { Recognise coupled } \\
\text { socio-ecological } \\
\text { systems }\end{array}$ & $\begin{array}{l}\text { Recognises the contribution of humans within whale } \\
\text { ecosystems, as well as multiple links from whale } \\
\text { ecosystems to human well-being }\end{array}$ \\
\hline $\begin{array}{l}\text { Ecological integrity and } \\
\text { biodiversity }\end{array}$ & $\begin{array}{l}\text { Recognises the complexity of linkages between whale and } \\
\text { other ecosystems and species }\end{array}$ \\
\hline $\begin{array}{l}\text { Account for dynamic } \\
\text { nature of ecosystems }\end{array}$ & $\begin{array}{l}\text { Management plans and policies recognise and respond to } \\
\text { the fluxes of ecosystems, including the effects of climate } \\
\text { change on whale sanctuaries }\end{array}$ \\
\hline Sustainability & $\begin{array}{l}\text { Emphasises the aim of increasing stock abundance, in } \\
\text { addition to other environmental, economic and socio- } \\
\text { cultural aspects linked to whale sanctuaries }\end{array}$ \\
\hline $\begin{array}{l}\text { Integrated management } \\
\text { Promotes shared management responsibility between } \\
\text { decision-makers (governance bodies) and stakeholders }\end{array}$ \\
\hline $\begin{array}{l}\text { Stakeholder } \\
\text { involvement }\end{array}$ & $\begin{array}{l}\text { Engaged stakeholders in the management planning } \\
\text { processes to build consensus concerning management plans } \\
\text { and policies }\end{array}$ \\
\hline $\begin{array}{l}\text { Incorporates management decisions based on best available } \\
\text { science }\end{array}$
\end{tabular}




\begin{tabular}{ll}
\hline $\begin{array}{l}\text { Appropriate spatial and } \\
\text { temporal scales }\end{array}$ & $\begin{array}{l}\text { Recognises that management plans and policies must be } \\
\text { spatially defined, but also accounts for temporal factors } \\
\text { related to the dynamics of the ecosystem }\end{array}$ \\
\hline Adaptive management & $\begin{array}{l}\text { Continues to improve management plans and policies } \\
\text { through systematic evaluation over time and in response to } \\
\text { new scientific data }\end{array}$ \\
\hline $\begin{array}{l}\text { Consider ecosystem } \\
\text { connections }\end{array}$ & $\begin{array}{l}\text { Considers how the dynamics of whale ecosystems and } \\
\text { imposition of management plans and policies affect other } \\
\text { species and ecosystems in the sanctuary and beyond }\end{array}$ \\
\hline
\end{tabular}

308

309

310

311

312

313

314

315

316

317

318

319

320

321

322

323

324

325

326

327

328

329

330

331

332

333

334

335

336

337

338

339

340

341

342

343

344

345

346

347

348

\section{Data and methods}

A qualitative case study approach was undertaken to examine the extent to which each study site accorded with the principles of EBM. This was conducted in line with the general rubric advised by Yin (1994), whose work outlined the necessary features of exploratory and descriptive analysis: construct validity, internal validity, external validity and reliability. With regards to reliability, the decision to report on the research outcomes from six whale sanctuaries around the world was made in order to minimise the dangers of generalisations associated with results from one detailed case study. As this study was principles-based, the choice of six case studies from around the world was deemed sufficient to generalise concerning the contribution of whale sanctuaries to marine EBM and the typical deficiencies - a single case study focus would be necessary to analyse the requirements for transition to full compliance specific to each study. In addition, the interpretations of the case study outcomes in terms of compliance with the criteria for marine EBM were supported and refined through a series of six semi-structured interviews.

\subsection{Selection of case studies}

Three selection criteria were applied when determining the six case studies to focus on: (a) IWC designation; (b) formal classification as an MPA by the IUCN; and (c) evidence of multiple uses of whale sanctuaries e.g. whaling, whale watching and other economic activities. With regards to the priority given to the selection criteria, criteria (a) and (b) were given priority, as the main aim of this paper is to evaluate the extent to which deemed protected areas correspond to EBM. For cases when criteria (a) and (b) did not apply, criteria (c) helped to focus the authors on the whale sanctuaries of likely greatest complexity in terms of integrated management, sustainability and ecosystem service implications, the core themes of marine EBM. The eventual set of six case studies was selected from an initial review of twenty-three possibilities, which included the whale sanctuaries listed in the study by Hoyt (2012) on marine protected areas for whales, dolphins and porpoises. Based on the information available in Hoyt (2012) and online desktop research, it was determined that criteria (c) would apply to whale sanctuaries involving at least four distinct economic activities, ensuring that the most complex case studies were identified for analysis. Of the six selected studies, two were identified based on criteria (a), one due to (b), and a further three via (c).

The case studies selected for analysis in this paper are as follows: (1) Indian Ocean Whale Sanctuary, (2) Southern Ocean Whale Sanctuary, (3) Hawaiian Islands Humpback Whale National Marine Sanctuary, (4) Faxaflói Bay Whale Sanctuary, (5) Whale Sanctuary of El 
Vizcaino, and (6) Sanctuary Ninginganiq (Bowhead Whale Sanctuary) National Wildlife Area. The locations and scale of the respective sanctuaries are shown in Fig. 2. The first three of these case studies were selected on the grounds of criteria (1) and (2); the final three were chosen on the basis of criteria (3). Faxaflói Bay is the centrepiece in the often heated debate in Iceland concerning the merits of whale watching and whaling, activities which currently occur alongside each other (Bertulli et al., 2016). El Vizcaino is a complicated coastal and predominantly land-based ecosystem in Mexico deemed to be of sufficient universal value that it is on the UNESCO World Heritage List (Mayer et al., 2018). Ninginganiq is located in Arctic Canada, close to an indigenous community on the Clyde river, and constitutes the world's first bowhead whale sanctuary (Lemelin and Dawson, 2014). 
Fig. 2: Location map of selected whale sanctuaries

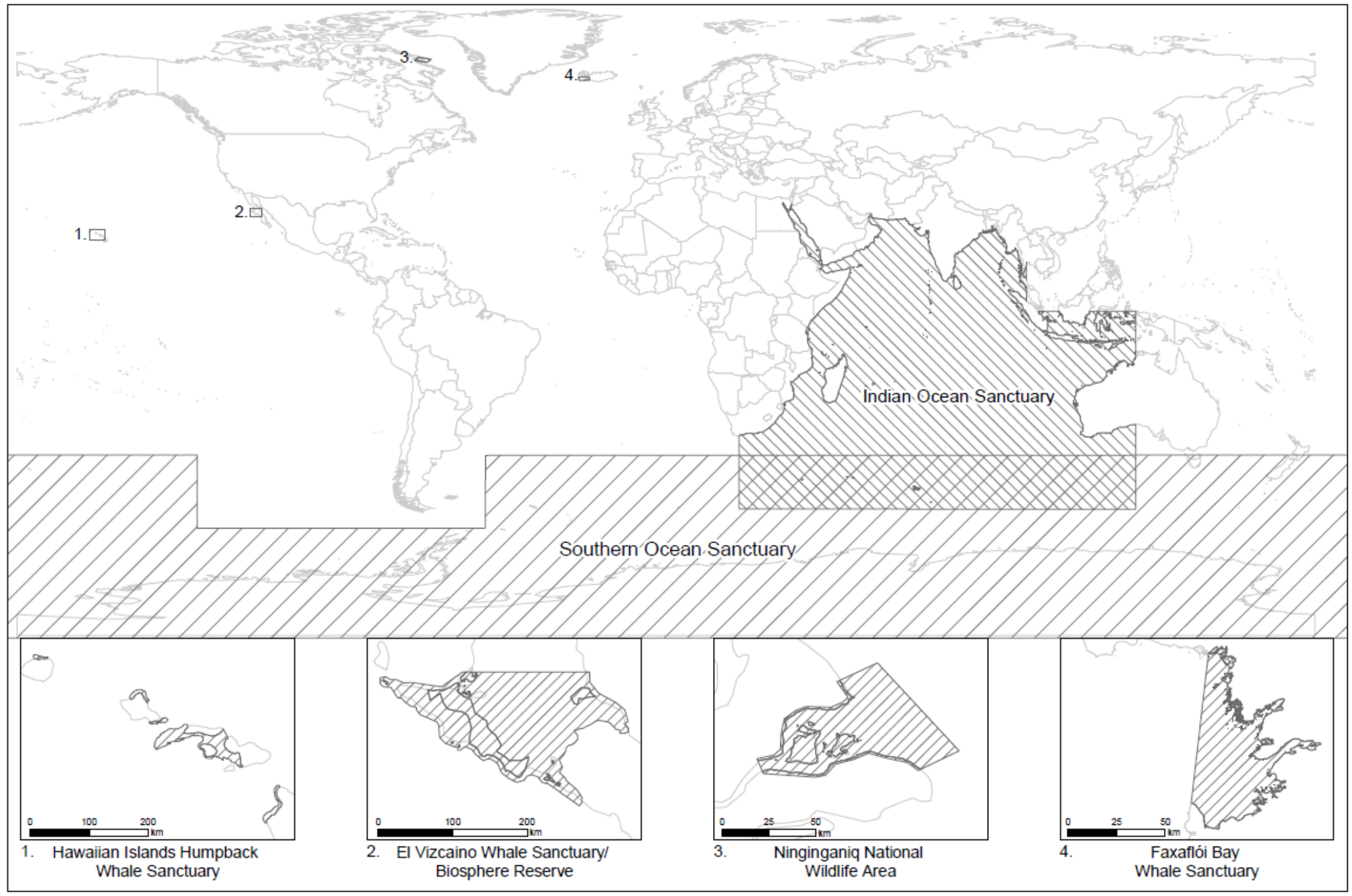




\subsection{Description of case studies}

The Indian Ocean's whale sanctuary covers approximately 50 million square kilometres and was established in 1979, banning all commercial whaling following a proposal by the Republic of the Seychelles at the 1979 meeting of the IWC (IWC, 1980). It consists of waters as far south as $55^{\circ}$ latitude, bounded to the west at $20^{\circ}$ longitude by Africa, with an eastern boundary of $130^{\circ}$ longitude by Australia. Although only $7 \%$ of the global catch of great whales occurred in the Indian Ocean at the time of the sanctuary's creation, the Indian Ocean was deemed to represent an important breeding ground for multiple species (Hoyt, 2012).

The IWC's second sanctuary in the Southern Ocean surrounding Antarctica was established in 1994 and also covers approximately 50 million square kilometres (IWC, 1995). All types of commercial whaling are banned, although Japan has continued to conduct some whaling activities, citing a need to conduct scientific research (Brierley and Clapham, 2016). This sanctuary is bounded to the north by the $40^{\circ}$ south latitude line, apart from in the Indian Ocean sector where the Indian Ocean Sanctuary takes precedence. The boundary to the south in the South Pacific and South America is the $60^{\circ}$ south latitude line (IWC, 1995).

Created in 1992, the Hawaiian Islands Humpback Whale National Marine Sanctuary is much smaller than the IWC's oceanic designations, spanning the distance from the shoreline to the 100-fathom isobaths in the four island areas of Maui; Penguin Bank; off the north coast of Kauai, the north and south shores of Oahu, and the north Kons and Kohala coast of Hawaii Island (NOAA, n.d.). In total, the sanctuary covers 3,555 square kilometres (Protected Planet, 2018). Management is administered by the US Department of Commerce's National Oceanic and Atmospheric Administration through their Office of National Marine Sanctuaries (NOAA, n.d.).

Following heated debate concerning the respective merits of whaling and whale watching, in 2009 Iceland's Marine Research Institute suggested areas of protection in Iceland where whaling would not be permitted. This included an area in Faxaflói Bay, adjacent to Iceland's capital city of Reykjavík, where commercial whaling would not be permitted and whale watching was most frequent (Rasmussen, 2014). Although the size of the sanctuary has varied over time, it was recently enlarged by Regulation 1035/2017 to comprise an area of 1,800 square kilometres located to the east of a straight line between Garðaskagi in the south and Skógarnes in the north (Stjórnarráð Íslands, 2017).

Formed in 1993, the El Vizcaino sanctuary is a UNESCO world heritage site located on the Pacific Coast of the central strip of Mexico's Baja California Peninsula. It consists of two coastal lagoons, Laguna San Ignacio and Laguna Ojo de Liebre, and surrounding wetlands, marshes, mangroves, dunes, halophytes and desert habitats. Combined, the ecosystems cover 3,710 square kilometres, a relatively small area within the much larger El Vizcaino Biosphere Reserve. The formation of the sanctuary was motivated by a need to manage sustainably the breeding grounds of the North Pacific Grey Whale, which had been hunted to near extinction (UNESCO, n.d.).

In 2009, the world's first bowhead whale sanctuary was formed in Ninginganiq around the north-east coast of Baffin Island, with commercial whaling banned in an area of approximately 3,360 square kilometres. The area is a late summer and early fall feeding and resting location for between 150 to 200 of the threatened Davis Strait-Baffin Bay bowhead whale population (Lemelin and Dawson, 2014). Under Article 26 of the Nunavut Land Claims 
Agreement and related Inuit Impact and Benefit Agreement, the local indigenous population retain rights to conduct a limited amount of traditional whaling (Government of Canada, 2017).

\subsection{Data collection through desktop research and interviews}

Following the collection of information via a desktop study of legal documents, management plans and academic analyses, each of the case studies was reviewed with regards to its adherence to Long et al.'s fifteen criteria of marine EBM. Interviewees were selected based on the knowledge of the authors concerning suitable persons, a desktop review of individuals with expertise and/or employment related to the planning and/or management of the respective whale sanctuaries, and in one case the recommendation of the second interviewee. Interviewees were contacted by email and requested to contribute to an anonymous validity, verification and information-gathering exercising concerning the design, planning and management of the whale sanctuary specific to their experience. The six interviews all took place via Skype in the period January to March 2019, were recorded and lasted for a duration of between 31 and 44 minutes.

Interviewees were first asked to provide their own assessment of compliance with marine EBM criteria, specific to their case study of expertise and in accordance with the approach undertaken in Table 2 of this paper. Where assessment interpretations differed between the authors and interviewees, the reasons were discussed and reflected upon, with outcomes refined accordingly. In particular, the interviews were focused on:

- The management of the whale sanctuaries, with each interviewee asked to comment on the monitoring, enforcement and penalty mechanisms;

- Contribution of participatory processes to decision-making and management outcomes;

- Strengths and limitations of the sanctuaries in the light of marine EBM;

- Marine EBM lessons for other whale sanctuaries (if any);

- Future improvements necessary to transition towards enhanced marine EBM for the sanctuary.

\subsection{Analysis}

Information obtained from the desktop study was analysed based on the principles of manifest analysis, as set out in the four-stage framework described by Bengtsson (2016): (1) surface structure (what had been said?); (2) recontextualisation (what was relevant?); (3) categorisation (with respect to the framework of Long et al.); and (4) compilation (the drawing of realistic conclusions). In order to provide an easy-to-understand summary of the conceptual outcomes, an evaluative matrix was developed during Stage 4, based on a trafficlights system to demonstrate compliance (green), non-compliance (red) or partial compliance (yellow). Stage 4 involved the contribution of the authors and the insights gleaned from the interviewees to validate the authors' initial findings.

\section{Results}

Table 2 sets out the evaluative matrix concerning the performance of each whale sanctuary with respect to the principles of marine EBM identified by Long et al. (2015). Thereafter, the 
text summarises examples from each of the case studies to illustrate the main tendencies of whale sanctuaries with regards to marine EBM compliance. Due to space constraints, it is not possible to provide a comprehensive review of each case study. 
All of the reviewed whale sanctuaries are typified by two characteristics which contribute to EBM. They acknowledge uncertainty in the sense that they take a highly precautionary approach - a blanket ban - to all forms of commercial whaling. In addition, the spatial boundaries of their designation are all clearly defined, the most basic expectation of any protected area. The precautionary motive behind the imposition of whale sanctuaries seems to be motivated by an array of concerns concerning the conservation of stocks and vital habitats, as well as some political objectives. In Ninginganiq, the focus is on preserving the habitat of copepods, a crustacean which is the dominant food source for the bowhead whale, which, with a typical lifespan of over 200 years, is the longest-lived mammal on the planet (Pomerleau et al., 2014). With regards to the IWC's large-scale designations in the Indian and Southern Oceans, their origins appear to have some political motivations, acting as a backup procedure in case the IWC's moratorium on commercial whaling ceases to have effect (Gerber et al., 2005).

\subsection{Variations in scope of whale sanctuaries}

The scope of each whale sanctuary is either narrow or broad, with the latter determined by the overall objectives of surrounding marine protected areas. Where whale sanctuaries such as those in Hawaii, El Vizcaino and Ninginganiq are located within marine reserves of a larger size and scope, these designations accord more fully with the principles of marine EBM. However, there were two closely related criteria in which all of the case studies were deemed to be deficient: ecological integrity and biodiversity, and accounting for the dynamic nature of ecosystems. The former is exemplified by the whale sanctuary in El Vizcaino. In this case, an assessment in 2014 by the IUCN, entitled 'Conservation Outlook 2014', asserted that the site was of low concern and stable in relation to its biodiversity. However, the report also cautioned that a number of lightly regulated or unregulated impacts could affect biodiversity in the future, especially linked to the depletion of freshwater aquifers and climate change. Threats necessitating close attention, monitoring and management procedures were cited as inappropriate tourism development, accidental release of brine into lagoons, and exploration and development of oil, gas, geothermal resources and mining (IUCN, 2014). Failure to account for future ecosystem dynamics was a theme across all of the sanctuaries, particularly with respect to the likely impacts of climate change and the development of new industries. The Indian Ocean sanctuary typified these deficiencies, given that cetaceans are exposed to a range of threats, including climate change and bycatch (De Boer, 2003; Sorby, 2018). The IWC's two designations and Faxaflói Bay highlighted the limitations of some whale sanctuaries in terms of marine EBM, with no management planning occurring in relation to activities such as shipping, fishing and tourism.

Even the Hawaiian Islands Humpback Whale National Marine Sanctuary, the most comprehensive of the case studies in terms of their contribution to marine EBM, has not yet transitioned its assessment and management planning to the extent that it conducts annual monitoring of stocks and fully accounts for and reconciles the other economic interests occurring in its waters. The latter deficiency necessitates explicit recognition of coupled socio-ecological systems, criteria which embeds the ecosystem services concept into marine spatial planning. In Hawaii, no studies have taken place which have sought to evaluate the contribution of marine ecosystem services to human well-being, either using monetary or nonmonetary information. The objectives of the Sanctuary, as enshrined in law, were fourfold and focused on (1) conservation stocks and habitat; (2) education and information provision; (3) 
management of human uses in the sanctuary to ensure conservation of stocks and habitats; and (4) consideration of the merits of other ecosystems within the sanctuary. Objective (3) is not holistic in scope given its limited focus on whale species (Oceans Act, 1992). Objective (4) has the potential to stimulate a transition towards marine EBM, which was outlined as an initial proposal within the Draft Revised Management Plan and associated Draft Environmental Impact Assessment for the sanctuary (ONMS \& NOAA, 2015). However, this proposal has since been withdrawn following extensive debate about the merits of expanding the size of the protected area and need for a more detailed socio-economic evaluation concerning the costs and benefits of conserving a broader array of habitats and ecosystems, especially linked to extensive tourist activities in the sanctuary (Federal Register, 2016). Companies such as Trilogy Excursions conduct sunset trips, whale watching, sailing, and scuba diving in the sanctuary. With regards to the latter, many activities are motivated by a desire to experience the coral reef ecosystem. This is the only ecosystem in the sanctuary which has been subject to an economic evaluation, a study which sought to estimate the Total Economic Value of the coral reef ecosystems surrounding the Main Hawaiian Islands (Bishop et al., 2011). The study was limited in focus to net economic value, estimated via surveys of how much people were willing to pay to preserve the coral reef ecosystem, including the valuations of people who had never visited the reefs. A broader economic valuation study on the coral reef ecosystem would also encompass associated impacts to the economy, especially effects on employment and income.

Understanding the impacts of whale sanctuaries and how they are managed is also a part of the sustainability criteria of marine EBM. In all of the case studies, there were at least some limitations in terms of embedding ecological, economic and social criteria into marine spatial planning. These were most prominent in the cases of the IWC's sanctuaries and Faxaflói Bay. With regards to the former, even determining in isolation the conservation rationale of the decision to ban all commercial whaling is difficult. For example, the Southern Ocean ban on commercial whaling affects nine migratory species of large cetaceans in their summer feeding grounds. Of these, one, minke whales, could have been caught under a science-based harvesting mechanism grounded in the principles of maximum sustainable yield (Zacharias et al., 2006). Moreover, viewed as a system, the IWC's sanctuaries fail to account for any of the other human-induced impacts on the marine environment, including ship strikes, bycatch, fishing and plastic pollution, as well as climate change effects. No other cultural or economic aspects are considered in relation to the management of the IWC's sanctuaries. Faxaflói Bay's sanctuary is similar in design, but its formation was motivated by political recognition of the need to allocate a dedicated area in the Bay to burgeoning whale watching (Rasmussen, 2014), acknowledging the merits of cultural ecosystem services in the form of tourism.

\subsection{Stakeholder consultation, participatory planning and management of whale sanctuaries}

Other whale sanctuaries have gone much further in advancing the integration of cultural values and knowledge into marine spatial planning, contributing to their sustainability credentials, stakeholder engagement and societal decision-making. The case study of Ninginganiq illustrates the potential for local collaboration to not only advance the creation of whale sanctuaries, but also to assist in co-management alongside scientific bodies. Establishing the sanctuary for bowhead whales as part of a National Wildlife Area was a consequence of many years of negotiation and gained the support of local, territorial and national agencies, including the Namautaq Hunters' \& Trappers' Organization, the Qikiqtaaluk Wildlife Board, the Department of Sustainable Development, Government of Nunavut, the Kakivak Corporation, Nunavut Research Institute, the Department of Fisheries 
and Oceans, the Canadian Wildlife Service, WWF-Canada, the Wildlife Section of Nunavut Tungavik Inc., and the Clyde River Economic Development Society (ECCC, 2017). This was an Inuit-led proposal which facilitated the protection of a species that had previously been brought close to extinction by non-indigenous, commercial whaling. Traditional indigenous and scientific knowledge is integrated in Ninginganiq through an approach of co-management (ECCC, 2017; Lloyd-Smith, 2017). A collaborative government and traditional owner relationship has been established and formalised between the Canadian Government and Inuit of Nunavut via the Inuit Impact and Benefit Assessment (Government of Canada, 2017). This agreement applies to the Ninginganiq National Wildlife Area, which is co-managed by the local Inuit community and the Canadian Wildlife Service. It is an approach that has led to the establishment of a Habitat Stewardship Program, tasked with monitoring the critical habitat of bowhead whales and reliant on further stakeholder input from Clyde River residents, scientists, NGOs, the Hunters' and Trappers' Organization, and the WWF (Wenzel et al., 2016; Lloyd-Smith, 2017).

Collaboration, community consultation and involvement are also hallmarks in the Hawaiian Islands Humpback Whale National Marine Sanctuary, features reinforced via the legislative documents enshrining the sanctuary's existence. The sanctuary was created in 1992 under the Hawaiian Islands National Marine Sanctuary Act, (P.L. 102-587, amended by P.L. 104-283) and strengthened through a Memorandum of Agreement signed in 2010 by the US Department of Commerce, National Oceanic and Atmospheric Administration, National Ocean Service, and Office of National Marine Sanctuaries. The Memorandum set out the mission for the Sanctuary, which is to protect humpback whales and their habitat through a wide range of activities in conservation, research, education, and outreach efforts to enhance public awareness, understanding, and appreciation of humpback whales and the Hawaiian Island marine environment (DC, NOAA, NOS \& ONMS, 2010). Research activities are overseen by a Sanctuary Advisory Council, established in 1996, who fund an assortment of educational, research and outreach activities, including a visitor centre (NMS \& NOAA, n.d.). Scientific research is focused upon gaining knowledge of humpback whale populations and their habitat. This is done through photo identification, behavioural studies, and studies on population, birth and mortality rates. In addition, the Sanctuary Advisory Council provides advice to a management body on the designation and/or operation of the national marine sanctuary. Council members disseminate information about the sanctuary and highlight the concerns of constituents and the public to the attention of sanctuary management. The Sanctuary Advisory Council is comprised of 52 primary and alternate members. Voting members represent the Islands of Molokai, Lani, Kauai, Hawaii, Maui, and Oahu in addition to local user groups, Native Hawaiian cultural advisors, fishing, business, conservation, science, education, and community representatives (Morin, 2001; NMS \& NOAA, n.d.). Through this structure and various activities, the Hawaiian case study is deemed to comply with EBM criteria relating to integrated management, stakeholder involvement, and use of scientific knowledge, and contributes to partial compliance for its sustainability credentials.

Integration of indigenous knowledge, provision of education, stakeholder consultation and comanagement are contributing forces towards integrated management. However, the case studies reveal that this is unlikely to lead to adaptive management, unless spatial plans are subject to regular review to account for changing ecosystem dynamics and the latest scientific data. The El Vizcaino case study illustrates this observation. Management is the responsibility of Mexico's National Commission of Natural Protected Areas, who divide the overall Reserve into 16 core zones in which permitted activities are restricted to research, recreation, tourism and environmental education (Hill et al., 2015; Mayer et al., 2018). 
Beyond the core zones is a buffer zone, the goal of which is to maintain ecosystem conditions, processes and functions, objectives which do not prevent industrial activities occurring in the Sanctuary. Management is theoretically guided by an overarching Conservation and Management Program, but this has not been revised since the year 2000. Conflicts and tradeoffs between the Sanctuary and other economic uses, including whale watching, fishing and salt extraction, are not yet reconciled in spatial planning, nor have local community interests tied to these activities been quantified economically (Hill et al., 2015; Mayer et al., 2018).

Stakeholder consultation is a necessary feature in understanding ecosystem service trade-offs in relation to whale sanctuaries (Hill, 2016). At one extreme, the case of Faxaflói illustrates how political meddling and ideology can be defining factors in setting a sanctuary's size and its management, involving no forms of public consultation on the part of its governance institutions. Public preference surveys in Iceland have reported $48 \%$ support for the sanctuary's existence and a recent survey by Malinauskaite et al. (2019) found that almost one-third of a nationally representative sample were in favour of its expansion. This is contrasted with the case of Hawaii, whereby a Memorandum of Agreement was signed in 2010 between the management bodies (this occurs via a cooperative federal-state partnership between the NOAA's Office of National Marine Sanctuaries and the State of Hawaii through the Department of Land and Natural Resources), conferring upon them a duty to stakeholders and communities to adopt policies in line with the conservation objectives of the sanctuary and to provide support in addressing their local resource protection needs (DC, NOAA, NOS \& ONMS, 2010). Public consultation was central to the ongoing revision to the Management Plan for the Hawaiian Islands Humpback Whale National Marine Sanctuary, which initially proposed an expansion in scale and transition to full marine EBM. The NOAA received 15,337 public comments from individuals, organisation, companies and agencies, with 11 public meetings to gather these comments (Federal Register, 2016).

\subsection{Determining the success of whale sanctuaries}

The success of whale sanctuaries is often determined by changes in stock sizes in the period following their creation (Hinch and de Santo, 2011). By this benchmark alone, many could be deemed to be successful, although the causal connection is often unclear. In Hawaii, the population of North Pacific humpback whales using the Sanctuary as a principal wintering ground has increased from 4,000 in 1993 to over 10,000 today (Pack et al., 2017). This is clearly partly due to the Sanctuary but also stems from the effectiveness of the wider international ban on commercial whaling, as well as national protections secured from the US Endangered Species Act and the Marine Mammal Protection Act. Stock sizes might be even greater through the full integration of marine EBM principles into the revised Management Plan, which could address remaining concerns linked to bycatch, entanglement in marine debris, such as fishing gear, and occasional fishing collisions which persist despite a 100-yard ban on approaching marine mammals (Gittings et al., 2013). Additionally, in the IWC's largescale designations, it is very difficult to establish any monitoring mechanism for determining success. A stated objective of the IWC's sanctuaries is to compare whale stocks within and outside of the protected area boundaries. However, the scale of sanctuaries renders this a difficult and potential misleading endeavour - for instance, in the Southern Ocean Sanctuary, baleen whale stocks within the sanctuary must be compared to stocks in warmer ocean waters north of $40^{\circ}$ (Botsford et al., 2003). Successful monitoring and enforcement of whale sanctuaries perhaps occurs more practically in smaller designations with attentive management, such as Ninginganiq. Here, the co-management approach between local Inuit leaders and wildlife managers has developed a 100-year Conservation Strategy for Bowhead 
Whales in Nunavut (Moschenko et al., 2003). Monitoring of stocks is directed by comanagement and takes place through community involvement, with a combination of in-class teaching and subsequent in-the-field documentation of population stocks and information gaps.

\section{Discussion}

\subsection{Transitioning to marine EBM in whale sanctuaries}

The case study review elicits a number of ways in which whale sanctuaries contribute and fail to adhere to the principles of marine EBM. Major deficiencies relate to the lack of marine spatial planning linked to objectives broader than the conservation of whale stocks, failure to assess the contribution of the sanctuary to human well-being and trade-offs in ecosystem services, lack of accounting for ecological and socio-economic dynamics, and absence of stakeholder consultation and participatory management. The extent of these deficiencies largely relates to whether the whale sanctuary forms part of a larger marine reserve with explicit conservation objectives, broader goals and stakeholder participation processes, and an evolving management plan. Although even the IWC's large-scale whale sanctuaries have been long-established in their current form, marine species and habitat conservation has advanced since their creation in other MPAs, not least through the increased deployment of marine EBM. Many of the deficiencies observed in this paper with regards to marine EBM could be resolved.

In the first instance, three of the whale sanctuary case studies - the IWC's two designations and Faxaflói Bay - lack conservation objectives associated with either an IUCN Category IV area or a whale sanctuary existing as part of broader marine reserve with multiple objectives. Thus, the clear establishment of broad overarching goals is important, focused foremost on conservation and biodiversity ideals but also criteria linked to other economic activities occurring in the sanctuary, such as fishery yields. Goals and objectives need to be developed following extensive consultation with scientists and stakeholders, a starting point in beginning to understand the sustainability and human well-being implications of different marine spatial planning permutations.

Once objectives are clarified and enshrined in policy documents, it is important for management plans to be developed. These need to build a strategy to ensure the core objectives are met, whilst helping to identity the institutional arrangements necessary to transition towards marine EBM. As was evidenced in the case of the Hawaiian Islands Humpback Whale National Marine Sanctuary, collaboration with existing and funding of new research programmes can assist in building the required information to develop a sanctuary management plan. Much of this is likely to be focused on the gathering of ecological baseline data. Zacharias et al. (2006), in their review of the IWC's sanctuaries, called for the collection of bio-geographic data of habitats and communities at the genetic, stocks, species, community and ecosystem levels. In the case of all whale sanctuaries, whale populations need to be identified both within and outside its boundaries, with threats to whale populations identified, including the anticipated impacts of ocean changes driven by climate change. In so doing, vulnerable areas within sanctuaries, especially the large-scale designations, can be identified, and consideration given to their spatial and temporal variability. The rapidity of likely changes should inform the debate concerning the need to revisit, reconsider and redraft management plans accordingly. Maintaining the involvement of stakeholders throughout the development of objectives and spatial plans, and management processes thereafter, helps to 
provide an integrated approach to management with human well-being, business and ecological interests accounted for. This was evidenced via the co-management approach adopted in Ninginganiq. A final requirement concerns the linking of objectives and management plans to monitoring strategies and indicators of success. The establishment of a Sanctuary Advisory Council in Hawaii helped to facilitate ongoing monitoring of whale stocks and the health of habitats, and an eventual transition to full marine EBM would need to establish indicators linked to a broader array of ecological and socio-economic criteria.

The purpose of this paper was to zoom in on whale sanctuaries and focus on their contribution to marine EBM. There are other types of marine protected areas that are not specifically labelled as 'whale sanctuaries' but can be effective, perhaps even more so, in conserving whale stocks and contributing to marine EBM, albeit all designations face challenges when ecosystems are multi-use and involve several economic actors. One example is Península Valdés in Patagonia, which has become a site of global significance for the conservation of marine mammals. Home to orcas, the site is also the world's most important breeding location for the endangered southern right whale (Nijs and Rowntree, 2017). A biosphere reserve rather than a whale sanctuary, it exhibits many of the features advocated within Long et al.'s (2015) framework for marine EBM. A strict biosphere reserve for Península Valdés was established in Golfo Nuevo in 1995, building on previous designations such as the 1974 Golfo San Jose Provincial Marine Park and 1983 formation of a Nature Reserve for Integrated Tourism Development (Deguignet et al., 2017). Management is led by the Chubut Provincial Tourism Organisation, with monitoring and enforcement by wildlife guards, the local police and the National Coastguard. Since much of the coastline is privately owned, decision-making is driven by stakeholder consultation and informed by research programmes at the National Centre for Patagonia. Through these informative and participatory planning processes, the Peninsula System Management Plan was developed and been in operation since 1998. Challenges include the environmental impacts from various economic sectors, especially tourism, where whale watching has resulted in disturbances to sensitive breeding populations, and pollution from sewage treatment works, fish processing and industry located in the town of Puerto Madryn (Fazio et al., 2015; Chalcobsky et al., 2017; IUCN, 2017). There remain causes of human-induced mortality of whales through ship strikes and entanglements in fishing gear (IUCN, 2017).

5.2 Embracing the ecosystem services concept - a general failing of whale sanctuaries and marine protected areas

Identifying and informing trade-offs has never been of greater importance given the challenges of climate change and competing human uses for marine ecosystems, such as fishing, shipping, tourism, recreation and hydrocarbon exploration. In whale sanctuaries and other marine ecosystems, management choices have not traditionally focused on the interactions between ecological and human systems. However, in recent times, an expanding number of publications have focused on the topic of valuation linked to marine ecosystem services (ES), focused on informing decision-makers about the importance of marine ES to human welfare and the multiple implications of their loss (Börger et al., 2014; Sagabiel et al., 2016; Ferreira et al., 2017; Malinauskaite et al., 2019).

One of the major challenges in embedding the ES concept into marine spatial planning, be this in a whale sanctuary or other type of protected area, is the paucity of data. This was typified by the Hawaiian Islands Humpback Whale National Marine Sanctuary, which sought 
to transition to full marine EBM, but lacked any supporting studies of the social and economic benefits of doing so, especially linked to supplies of ecosystem services. If multiple habitats within whale sanctuaries are to be afforded a priority for conservation, then, in accordance with definitions of marine EBM, then decision-makers should be provided with information concerning the consequences to the quality and quantity of ES. This is an observation concerning all types of marine protected areas, and thus future work should focus on progressing baseline data on ecosystem service flows from marine and coastal ecosystems (Potts et al., 2014). As the recent study by Cook et al., (2019) discusses, in the context of whale ecosystem services, this is likely to involve the need for a mixture of monetary and non-monetary information, and ultimately integrated valuation platforms to support decisionmaking, such as Multi-Criteria Decision Analysis.

\subsection{Study limitations and future research}

This study relied on Long et al.'s (2015) framework for determining the main principles of marine EBM. Given the contestability of the concept in terms of its definition and measurement, this was a useful means of setting out the most common principles in the academic literature, and a frequency approach helped to identify the principles deemed to be most important. For a qualitative case study review such as this, seeking to establish performance tendencies rather than empirical evaluation, the framework was ideal for identifying general adherence and non-adherence with the core components of marine EBM. However, the generalisations formed from this study's case study approach cannot be extended beyond its six selected case studies, and were derived from the data available for the authors' review. Other information that may have been available in foreign languages, for example Spanish in the case of the El Vizcaino case study, was not included in the analysis.

Other weaknesses of the framework concerned the overlap between the fifteen principles. These were not distinct aspects of marine EBM, but connected, with certain principles difficult to distinguish from others. The most important criteria in the framework was determined to be the consideration of ecosystem connections, however, this is evidently a fundamental ingredient in ecological integrity and biodiversity, sustainability, and accounting for the dynamic nature of ecosystems. These principles were deemed to be less important than ecosystem connections due to Long et al's frequency approach, despite their interrelatedness. Equally, the same could be said of the principle 'decisions reflect societal choices', deemed less important but clearly a major factor in 'stakeholder involvement'. In addition, there is the potential that the Long et al. (2015) framework does not capture all aspects of marine EBM specific to every whale sanctuary. Overall, the usefulness of the framework in a case study review is in revealing generalisations, which was the purpose of the paper, but a study focused on how to transition a specific whale sanctuary to EBM should delve more deeply into the links between the various principles, refining and defining these to avoid duplication as much as possible.

\section{Conclusion}

Whale sanctuaries are traditionally focused on conservation objectives through the adoption of a ban on commercial whaling. As such, they are commonly considered to represent protected areas. This paper applied a case study approach to review six whale sanctuaries from around the world, evaluating the extent to which they adhered to the 15 criteria of 
marine EBM outlined by Long et al. (2015). The degree of compliance with the criteria of Long et al. (2015) depended greatly on whether the whale sanctuary existed as part of a larger marine reserve, one with clearly defined conservation objectives, broader in scope and more encompassing of stakeholder interests and participatory management. Understanding the economic and ecological trade-offs pertaining to different economic activities in whale sanctuaries is necessary for even the most comprehensive of the reviewed case studies, the Hawaiian Humpback Whale National Marine Sanctuary, in order for this area to adhere more fully with the principles of marine EBM. Economic and socio-cultural valuation of ecosystem service impacts needs to be expanded in the context of whale sanctuaries to better understand the human well-being implications of their current management and potential future design.

\section{Acknowledgements}

This paper has been funded by NordForsk (grant number 76654) via their financial support to the Nordic Centre of Excellence ARCPATH (Arctic Climate Predictions - Pathways to Resilient, Sustainable Communities).

\section{References}

Agardy, T., Di Sciara, G. N., \& Christie, P. (2011). Mind the gap: addressing the shortcomings of marine protected areas through large scale marine spatial planning. Marine Policy, 35(2), 226-232.

Arkema, K. K., Abramson, S. C., \& Dewsbury, B. M. (2006). Marine ecosystem-based management: from characterization to implementation. Frontiers in Ecology and the Environment, 4(10), 525-532.

Bengtsson, M. (2016). How to plan and perform a qualitative study using content analysis. NursingPlus Open, 2, 8-14.

Bertulli, C. G., Leeney, R. H., Barreau, T., \& Matassa, D. S. (2016). Can whale-watching and whaling co-exist? Tourist perceptions in Iceland. Journal of the Marine Biological Association of the United Kingdom, 96(4), 969-977.

Bishop, R. C., Chapman, D. J., Kanninen, B. J., Krosnick, J. A., Leeworthy, V. R., \& Meade, N. F. (2011). Total economic value for protecting and restoring Hawaiian coral reef ecosystems final report. NOAA Technical Memorandum. Silver Spring, MD.

Börger, T., Beaumont, N. J., Pendleton, L., Boyle, K. J., Cooper, P., Fletcher, S., Haab, T., Hanemann, M., Hooper, T.L., Hussain, S. S., Portela, R., Stithou, M., Stockill, J., Taylor, T. \& Austen, M. C. (2014). Incorporating ecosystem services in marine planning: the role of valuation. Marine Policy, 46, 161-170.

Botsford, L. W., Micheli, F. \& Hastings, A. (2003). Principles for the design of marine reserves. Ecological Applications, 13, 25-31. 
Brierley, A. S., \& Clapham, P. J. (2016). Whaling permits: Japan's whaling is unscientific. Nature, 529(7586), 283.

Chalcobsky, B. A., Crespo, E. A., \& Coscarella, M. A. (2017). Whale-watching in Patagonia: What regulation scheme should be implemented when the socio-ecological system is changing?. Marine Policy, 75, 165-173.

Charles, A. (2012). People, oceans and scale: governance, livelihoods and climate change adaptation in marine social-ecological systems. Current Opinion in Environmental Sustainability, 4(3), 351-357.

Christie, P., Bennett, N. J., Gray, N. J., Wilhelm, T. A., Parks, J., Ban, N. C., Gruby, R. L., Gordon, L., Day, J., Taei, S. \& Friedlander, A. M. (2017). Why people matter in ocean governance: Incorporating human dimensions into large-scale marine protected areas. Marine Policy, 84, 273-284.

COMPASS (Communication Partnership for Science and the Sea). (2005). Scientific consensus statement on marine ecosystem-based management. Retrieved from: http://www.compassonline.org/sites/all/files/document_files/EBM_Consensus_Statement_v1 2.pdf (accessed 12 $2^{\text {th }}$ October 2018).

Cook, D., Saviolidis, N. M., Davíðsdóttir, B., Jóhannsdóttir, L., \& Ólafsson, S. (2017). Measuring countries' environmental sustainability performance - The development of a nation-specific indicator set. Ecological indicators, 74, 463-478.

Cook, D., Malinauskaite, L., Davíðsdóttir, B. \& Ögmundardóttir, H. (2019). Valuing ecosystem services sourced from whales - informing trade-offs and decision-making. Ocean and coastal management. (IN REVIEW).

Crowder, L., \& Norse, E. (2008). Essential ecological insights for marine ecosystem-based management and marine spatial planning. Marine policy, 32(5), 772-778.

Day J., Dudley N., Hockings M., Holmes G., Laffoley, D., Stolton S. \& Wells, S. (2012). Guidelines for applying the IUCN Protected Area Management Categories to Marine Protected Areas. IUCN: Gland, Switzerland.

De Boer, M. N., Baldwin, R., Burton, C. L. K., Eyre, L., Jenner, K. C. S, Jenner, M. N. M, Keith, S. G., McCabe, K. A., Parsons, E. C. M, Peddemors, V. M., Rosenbaum, H. C., Rudolph, P., Thiele, D. \& Simmonds, M. (2003). Cetaceans in the Indian Ocean Sanctuary: a review. Whale and Dolphin Conservation Society. Chippenham, UK.

DC, NOAA, NOS \& ONMS (Department of Commerce, National Oceanic and Atmospheric Administration, National Ocean Service \& Office of National Marine Sanctuaries. (2010). Memorandum of Agreement - Pursuant to the National Marine Sanctuaries Act 16 U.S.C. 1442(e) between the U.S. Department of Commerce, National Oceanic and Atmospheric Administration, National Ocean Service, Office of National Marine Sanctuaries and the State of Hawaii Department of Land and Natural Resources for the purpose of coordinating management of the Hawaiian Islands Humpback Whale National Marine Sanctuary. NOS Agreement Code: MOA-2010-044 / 8148. Retrieved from: 
https://dlnr.hawaii.gov/dar/files/2015/10/MOA-2010-2015_Sanctuary.pdf (accessed 7th November 2018).

Deguignet, M., Arnell, A., Juffe-Bignoli, D., Shi, Y., Bingham, H., MacSharry, B., \& Kingston, N. (2017). Measuring the extent of overlaps in protected area designations. PloS one, 12(11), e0188681.

ECCC (Environment and Climate Change Canada). (2017). Evaluation of the Protected Areas Program. Retrieved from: http://www.ec.gc.ca/ae-ve/default.asp?lang=En\&n=6D0D0DAA$1 \&$ offset=3 (accessed $10^{\text {th }}$ November 2018).

Fazio, A., Argüelles, M. B., \& Bertellotti, M. A. R. C. E. L. O. (2015). Spatial and temporal dynamic of whale watching in Península Valdés, Patagonia, Argentina. Journal of Cetacean Research and Management, 15, 69-76.

Federal Register. (2016). Withdrawal of Hawaiian Islands Humpback Whale National Marine Sanctuary Regulations. Retrieved from: https://www.federalregister.gov/documents/2016/03/14/2016-05452/withdrawal-of-hawaiianislands-humpback-whale-national-marine-sanctuary-proposed-regulations (accessed 12th November 2018).

Ferreira, A. M., Marques, J. C., \& Seixas, S. (2017). Integrating marine ecosystem conservation and ecosystems services economic valuation: Implications for coastal zones governance. Ecological Indicators, 77, 114-122.

Gerber, L. R., Hyrenbach, K. D., \& Zacharias, M. A. (2005). Do the largest protected areas conserve whales or whalers?. Science, 307(5709), 525-526.

Giakoumi, S., McGowan, J., Mills, M., Beger, M., Bustamante, R., Charles, A., ... \& Guidetti, P. (2018). Revisiting "success" and "failure" of marine protected areas: a conservation scientist perspective. Frontiers in Marine Science, 5, 223.

Gittings, S.R., M. Tartt, and K. Broughton. (2013). National Marine Sanctuary System Condition Report 2013. U.S. Department of Commerce, National Oceanic and Atmospheric Administration, Office of National Marine Sanctuaries, Silver Spring, MD.

Government of Canada. (2017). 2016 to 2023 Inuit Impact and Benefit Agreement - for national wildlife areas and migratory bird sanctuaries in the Nunavit settlement area. Environment and Climate Change Ministry of Canada. Retrieved from: http://www.tunngavik.com/files/2017/05/6980_EC_IIBA_EN_F_av-4.pdf (accessed 26th October 2018).

Gruby, R. L., Gray, N. J., Campbell, L. M., \& Acton, L. (2016). Toward a social science research agenda for large marine protected areas. Conservation Letters, 9(3), 153-163.

Hilborn, R. (2016). Policy: Marine biodiversity needs more than protection. Nature News, 535(7611), 224.

Hill, W., Byrne, J., \& Pickering, C. (2015). The 'hollow-middle': why positive community perceptions do not translate into pro-conservation behaviour in El Vizcaíno Biosphere 
Reserve, Mexico. International Journal of Biodiversity Science, Ecosystem Services \& Management, 11(2), 168-183.

Hill, W. M. (2016). How inhabitants of protected areas perceive, participate in, and benefit from conservation in El Vizcaíno Biosphere Reserve, México. Doctoral dissertation, Griffith University, Australia. Retrieved from: https://experts.griffith.edu.au/publication/n50262f6af75da8508a82e1646a018cdd (accessed 14th November 2018).

Hinch, P. R., \& De Santo, E. M. (2011). Factors to consider in evaluating the management and conservation effectiveness of a whale sanctuary to protect and conserve the North Atlantic right whale (Eubalaena glacialis). Marine Policy, 35(2), 163-180.

Hoyt, E. (2005). Sustainable ecotourism on Atlantic islands, with special reference to whale watching, marine protected areas and sanctuaries for cetaceans. In Biology and environment: proceedings of the Royal Irish Academy (p. 141-154). Royal Irish Academy.

Hoyt, E. (2012). Marine protected areas for whales dolphins and porpoises: A world handbook for cetacean habitat conservation. Routledge: London.

ICRW (International Convention for the Regulation of Whaling). (1946). Retrieved from the Arctic Portal Library: http://library.arcticportal.org/1863/1/1946\%20IC\%20for\%20the\%20Regulation\%20of\%20W haling-pdf.pdf (accessed $23^{\text {rd }}$ October 2018).

IUCN (International Union for Conservation of Nature) (2008). Guidelines for applying protected area management categories, IUCN: Gland. Retrieved from: https://www.iucn.org/content/guidelines-applying-protected-area-management-categories (accessed 25th October 2018).

IUCN (International Union for Conservation of Nature) (2014). IUCN World Heritage Outlook 2014 - A conservation assessment of all natural World Heritage sites. IUCN: Gland. Retrieved from: https://portals.iucn.org/library/efiles/documents/2014-039.pdf (accessed 12th November 2018).

IUCN (International Union for Conservation of Nature) (2017). IUCN World Heritage Outlook Conservation Outlook - - A conservation assessment of all natural World Heritage sites. IUCN: Gland. Retrieved from: https://www.worldheritageoutlook.iucn.org/exploresites/wdpaid/198291 (accessed 13th November 2018).

IWC (International Whaling Commission). (1980). Annual Report of $31^{\text {st }}$ Meeting of the International Whaling Commission. Report of the International Whaling Commission: Histon.

IWC (International Whaling Commission). (1995). Annual Report of $46^{\text {th }}$ Meeting of the International Whaling Commission. Report of the International Whaling Commission: Histon.

IWC (International Whaling Commission). (1998). Annual Report of the International Whaling Commission. 50 ${ }^{\text {th }}$ annual meeting. Retrieved from: https://archive.iwc.int/pages/download.php?ref=2073\&size=\&ext... (accessed $23^{\text {rd }}$ October 2018). 
IWC (International Whaling Commission). (n.d.). Whale sanctuaries - establishment of the International Whaling Commission's sanctuaries. Retrieved from: https://iwc.int/sanctuaries (accessed 23 ${ }^{\text {rd }}$ October 2018).

Jones, P. J., \& De Santo, E. M. (2016). Viewpoint-Is the race for remote, very large marine protected areas (VLMPAs) taking us down the wrong track?. Marine Policy, 73, 231-234.

Kark, S., Brokovich, E., Mazor, T., \& Levin, N. (2015). Emerging conservation challenges and prospects in an era of offshore hydrocarbon exploration and exploitation. Conservation Biology, 29(6), 1573-1585.

Lemelin, R. H., \& Dawson, J. (2014). Great expectations: Examining the designation effect of marine protected areas in coastal Arctic and sub-Arctic communities in Canada. The Canadian Geographer/Le Géographe Canadien, 58(2), 217-232.

Lloyd-Smith, G. (2017). An Ocean of Opportunity: Co-governance in Marine Protected Areas in Canada. West Coast Environmental Law. Retrieved from: https://www.wcel.org/publication/ocean-opportunity-co-governance-in-marine-protectedareas-in-canada (accessed 11th November 2018).

Long, R. D., Charles, A., \& Stephenson, R. L. (2015). Key principles of marine ecosystembased management. Marine Policy, 57, 53-60.

Malinauskaite, L., Cook, D., Davíðsdóttir, B., Ögmundardóttir, H. \& Roman, J. (2019). Arctic ecosystem services: a literature review. Ecosystem Services, 36.

Malinauskaite, L., Cook, D., Davíðsdóttir, B., Ögmundardóttir, H. \& Roman, J. (2019). Willingness to pay for expansion of the whale sanctuary in Faxaflói Bay, Iceland: a contingent valuation study, Environmental Management (IN REVIEW).

Mayer, M., Brenner, L., Schauss, B., Stadler, C., Arnegger, J., \& Job, H. (2018). The nexus between governance and the economic impact of whale-watching. The case of the coastal lagoons in the El Vizcaíno Biosphere Reserve, Baja California, Mexico. Ocean \& Coastal Management.

Morin, T. (2001). Sanctuary advisory councils: involving the public in the National Marine Sanctuary Program. Coastal Management, 29(4), 327-339.

Moschenko, R., Cosens, S. E. \& Thomas, T. A. (2003). Conservation strategy for bowhead whales (balaena mysticetus) in the Eastern Canadian Arctic. National Recovery plan no. 24. Recovery of Nationally Endangered Wildlife (RENEW). Ottawa, Canada.

Murawski, S. A., Wigley, S. E., Fogarty, M. J., Rago, P. J., \& Mountain, D. G. (2005). Effort distribution and catch patterns adjacent to temperate MPAs. ICES Journal of Marine Science, 62(6), 1150-1167.

Nijs, G., \& Rowntree, V. J. (2017). Rare sightings of southern right whales (Eubalaena australis) on a feeding ground off the South Sandwich Islands, including a known individual from Península Valdés, Argentina. Marine Mammal Science, 33(1), 342-349. 
NMS \& NOAA (National Marine Sanctuaries and National Oceanic and Atmospheric Administration). (n.d.) Hawaiian Islands Humpback Whale National Marine Sanctuary Management. Retrieved from: https://hawaiihumpbackwhale.noaa.gov/council/welcome.html (accessed 7th November 2018).

NOAA (National Oceanic and Atmospheric Administration). (n.d.). Hawaiian Islands Humpback Whale National Marine Sanctuary. Retrieved from: https://hawaiihumpbackwhale.noaa.gov/ (26 ${ }^{\text {th }}$ October 2018).

Oceans Act. (1992). HINMSA, Subtitle C of Public Law 102-587, the Oceans Act of 1992, United States Congress.

OECD. (2001). Environmental strategy for the first decade of the $21^{\text {st }}$ century. OECD: Paris.

Olafsson, S., Cook, D., Davidsdottir, B., \& Johannsdottir, L. (2014). Measuring countries' environmental sustainability performance-A review and case study of Iceland. Renewable and Sustainable Energy Reviews, 39, 934-948.

ONMS \& NOAA (Office of National Marine Sanctuaries \& National Oceanic and Atmospheric Administration). (2015). Draft Management Plan and Draft Environmental Impact Statement. Silver Spring, MD. Retrieved from: https://nmshawaiihumpbackwhale.blob.core.windows.net/hawaiihumpbackwhaleprod/media/archive/management/pdfs/mp2015_dmp_deis.pdf (accessed 10th November 2018).

Pack, A. A., Herman, L. M., Craig, A. S., Spitz, S. S., Waterman, J. O., Herman, E. Y., ... \& Lowe, C. (2017). Habitat preferences by individual humpback whale mothers in the Hawaiian breeding grounds vary with the age and size of their calves. Animal Behaviour, 133, 131-144.

Pomerleau, C., Watkins, J. M., Archambault, P., Conlan, K., Ferguson, S., Gilchrist, G., Hedges, K., Loseto, L., Lovejoy, C., Michel, C., Nelson, R. J., Poulin, M., Richardson, E., Robertson, G. \& Stow, J. (2014). Canadian Arctic Marine Biodiversity Plan 2014-2017. Retrieved from: https://oaarchive.arctic-council.org/handle/11374/225 (accessed 12th November 2018).

Potts, T., Burdon, D., Jackson, E., Atkins, J., Saunders, J., Hastings, E., \& Langmead, O. (2014). Do marine protected areas deliver flows of ecosystem services to support human welfare?. Marine Policy, 44, 139-148.

Rasmussen, M. (2014). The whaling versus whale-watching debate. p. 81-94 in Sustainable Tourism and Management, Part II - Human dimensions of whale-watching. Cambridge University Press: Cambridge.

Sagebiel, J., Schwartz, C., Rhozyel, M., Rajmis, S., \& Hirschfeld, J. (2016). Economic valuation of Baltic marine ecosystem services: blind spots and limited consistency. ICES Journal of Marine Science, 73(4), 991-1003. 
Sorby, S. (2018). From universal to local law: prospects for the protection of whales in the western Indian Ocean through the Whale Route project. Western Indian Ocean Journal of Marine Science, 75-83.

Stjórnarráð Íslands. (2017). Reglugerð um bann við hvalveiðum á tilteknum svæðum. Reg.1035/2017. Retrieved from: https://www.stjornarradid.is/lisalib/getfile.aspx?itemid=228012d3-d514-11e7-9422005056bc530c (accessed 26 ${ }^{\text {th }}$ October 2018).

UNESCO (United Nations Educational, Scientific and Cultural Organization). (n.d.). Whale Sanctuary of El Vizcaino. Retrieved from: https://whc.unesco.org/en/list/554/ (accessed 26 ${ }^{\text {th }}$ October 2018).

UNEP-WCMC and IUCN. (2018). Marine Protected Planet. Online database retrieved from www.protectedplanet.net (accessed $25^{\text {th }}$ October 2019).

UNEP-WCMC (2017). The World Database on Protected Areas dataset. United Nations Environment Programme - World Conservation Monitoring Centre, Cambridge. Retrieved from: http://www.protectedplanet.net/c/ world-database-on-protected-areas (accessed $12^{\text {th }}$ October 2018).

United Nations. (2015). Transforming Our World: The 2030 Agenda for Sustainable Development. UN Publishing: New York. Retrieved from:

https://sustainabledevelopment.un.org/post2015/transformingourworld (accessed 15th October 2018).

Unsworth, R. K., Cullen, L. C., Pretty, J. N., Smith, D. J., \& Bell, J. J. (2010). Economic and subsistence values of the standing stocks of seagrass fisheries: potential benefits of no-fishing marine protected area management. Ocean and Coastal Management, 53(5), 218.

Watson, J. E., Dudley, N., Segan, D. B., \& Hockings, M. (2014). The performance and potential of protected areas. Nature, 515(7525), 67.

Wenzel, L., Gilbert, N., Goldsworthy, L., Tesar, C., Mcconnell, M., \& Okter, M. (2016). Polar opposites? Marine conservation tools and experiences in the changing Arctic and Antarctic. Aquatic Conservation: Marine and Freshwater Ecosystems, 26, 61-84.

Yin, R. K. (1994). Discovering the future of the case study. Method in evaluation research. Evaluation practice, 15(3), 283-290.

Zacharias, M. A., Gerber, L. R., \& Hyrenbach, K. D. (2006). Review of the Southern Ocean Sanctuary: marine protected areas in the context of the International Whaling Commission Sanctuary Programme. Journal of Cetacean Research and Management, 8(1), 1. 